\title{
Article \\ A Taguchi Approach for Optimizing Design Mixture of Geopolymer Concrete Incorporating Fly Ash, Ground Granulated Blast Furnace Slag and Silica Fume
}

\author{
Sundaravadivelu Karthik*(D) and Kaliyaperumal Saravana Raja Mohan \\ School of Civil Engineering, SASTRA Deemed University, Thanjavur 613401, India; srm@civil.sastra.edu \\ * Correspondence: karthik@civil.sastra.edu
}

\section{check for}

updates

Citation: Karthik, S.; Mohan, K.S.R. A Taguchi Approach for Optimizing Design Mixture of Geopolymer Concrete Incorporating Fly Ash, Ground Granulated Blast Furnace Slag and Silica Fume. Crystals 2021, 11, 1279. https://doi.org/10.3390/ cryst11111279

Academic Editors: Edyta Pawluczuk, Iwona Skoczko and Enrique

Fernandez Ledesma

Received: 19 September 2021

Accepted: 21 October 2021

Published: 22 October 2021

Publisher's Note: MDPI stays neutral with regard to jurisdictional claims in published maps and institutional affiliations.

Copyright: (c) 2021 by the authors. Licensee MDPI, Basel, Switzerland. This article is an open access article distributed under the terms and conditions of the Creative Commons Attribution (CC BY) license (https:/ / creativecommons.org/licenses/by/ $4.0 /)$.

\begin{abstract}
In recent decades, geopolymer concrete (GPC) has been extensively researched as a potential substitute sustainable building material that may reduce $\mathrm{CO}_{2}$ emissions due to its utilization of industrial by-products. Fly ash (FA) and ground-granulated blast-furnace slag (GGBFS) are preferred geopolymer raw materials due to their obtainability and high alumina and silica concentrations. GGBFS-FA based GPC offers a clean and sustainable development technology alternative. In this study, the Taguchi method was used to optimize the mixed proportions of geopolymer concrete to achieve desired strength criteria. Four factors and four levels were considered: binder content, including four combinations of FA and GGFBS dosage, dosage of superplasticizer $(0.5,1.0,1.5$ and $2 \%), \mathrm{Na}_{2} \mathrm{SiO}_{3} / \mathrm{NaOH}$ ratio $(1.5,2.0,2.5$ and 3$)$, and molarity $(6,8,10$ and 12). Using these ingredients and factors, the effect of compressive strength was examined. The Taguchi approach using an L16 orthogonal array was employed to find the optimum condition of every factor while limiting the number of experiments. The findings indicated that the optimum synthesis conditions for maximum compressive strength obtained from the binder comprised $45 \%$ of FA, $45 \%$ of GGBFS and $10 \%$ of silica fume, $1.5 \%$ dosage of superplasticizer, $\mathrm{Na}_{2} \mathrm{SiO}_{3} / \mathrm{NaOH}$ ratio $=1.5$, and 12 molar contents.
\end{abstract}

Keywords: geopolymer concrete; fly ash; mix design; Taguchi; silica fume; ANOVA

\section{Introduction}

Concretes with various purposes have become more popular as urban building has progressed at a fast pace. Researchers have evaluated several types of concrete that are commonly used, including heavy concrete [1], self-compacting concrete [2], gradient concrete [3], reinforced and prestressed concrete [4], and self-consolidating concrete [5]. The need for essential cement construction materials is progressively increasing. At the same time, the quantity of $\mathrm{CO}_{2}$ emissions from OPC manufacture continues to increase year-on-year due [6]. As a result, green construction materials must be used instead of conventional building materials which generate significant environmental damage. Environmentally friendly alternatives for binding materials include geopolymers and alkali-activated binders which are both considered environmentally friendly. According to Davidovits (2002) [7], the carbon dioxide emitted during production of $1 \mathrm{~kg}$ of geological polymer cement is $0.180 \mathrm{~kg}$, barely one-fifth of the amount emitted during the preparation of conventional silicate cement. In addition, some studies have shown that geopolymer concretes caused lower emissions of $\mathrm{CO}_{2}$ compared to the production of ordinary Portland cement [8], with the emissions decreasing by as much as $4 \%$ to $9 \%$ [9]. As a result, to effectively support the use of geopolymer in buildings, it is essential to investigate its more beneficial characteristics.

GPC is a potential green construction material that is also cost-effective. The by-products of the polymerization processes are known as geopolymers involving alkali activators and aluminosilicate-rich materials. The raw ingredients used in this process come from various sources, including metakaolin, GGBFS, and FA. The activators comprise sodium hydroxide 
$(\mathrm{NaOH})$ and sodium silicate $\left(\mathrm{Na}_{2} \mathrm{SiO}_{3}\right)$. The manufacturing process of GPC is shown in Figure 1. The benefit of GPC is that it replaces conventional cement concrete with industrial effluents, which saves money. The GPC can be produced using industrial waste as raw materials and has significant potential to enhance sustainability [10]. Until now, GGBFS and FA have been used mainly in GPC because of the wide availability of high alumina $\left(\mathrm{Al}_{2} \mathrm{O}_{3}\right)$ and silica $\left(\mathrm{SiO}_{2}\right)$ [11]. The combining of GGBFS, FA and OPC, is shown in Figure 2 [12]. As a result of the alternative combination options, the characteristics of GPC generated using various binding materials vary. Among the primary reaction products of GPC made using FA/GGBF are sodium aluminosilicate hydrate (N-A-S-H gel), calcium aluminosilicate hydrate (C-A-S-H gel), and calcium silicate hydrate (C-S-H gel), to give a few examples [13].

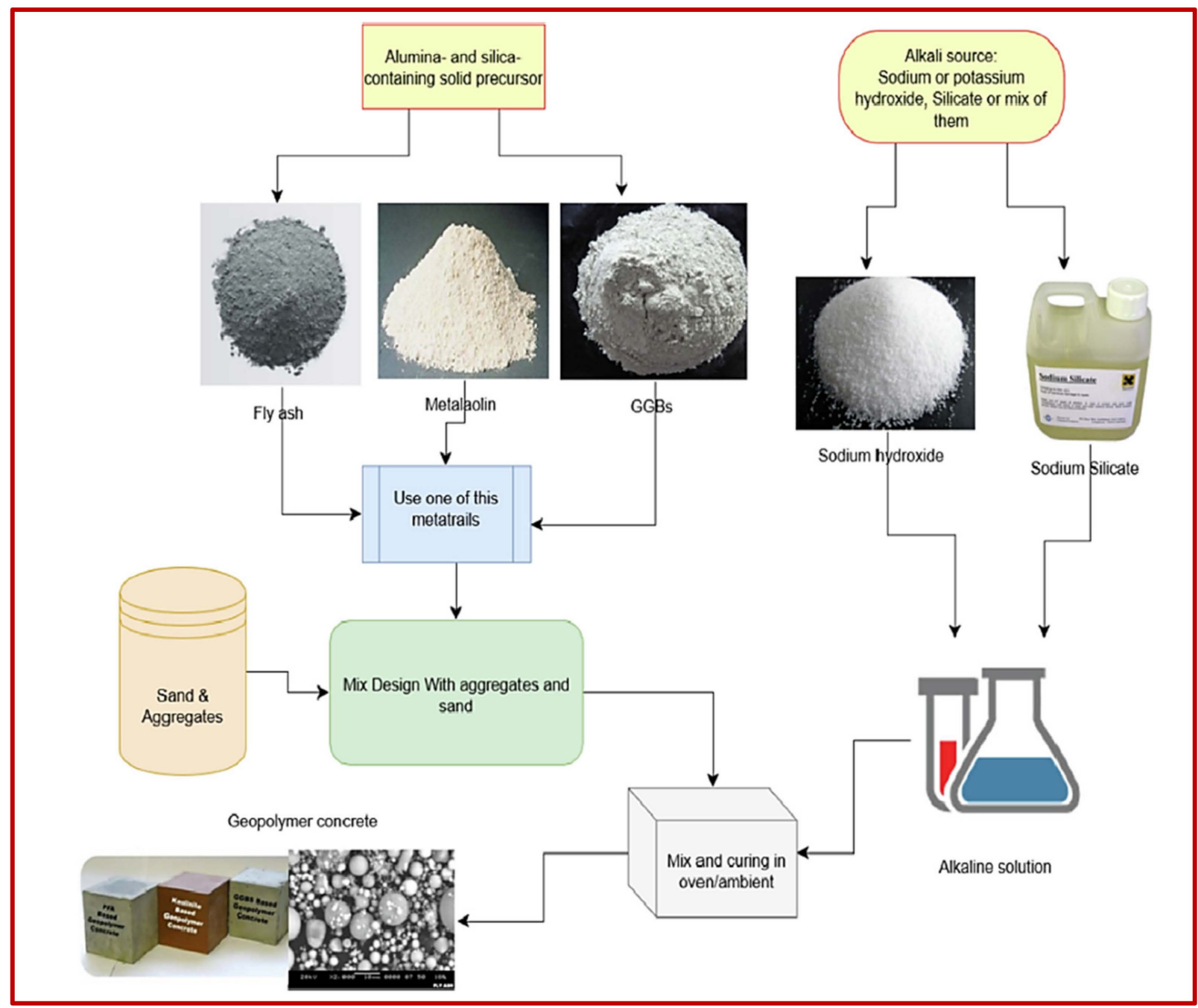

Figure 1. GPC manufacturing; reprinted with permission from [14]. 


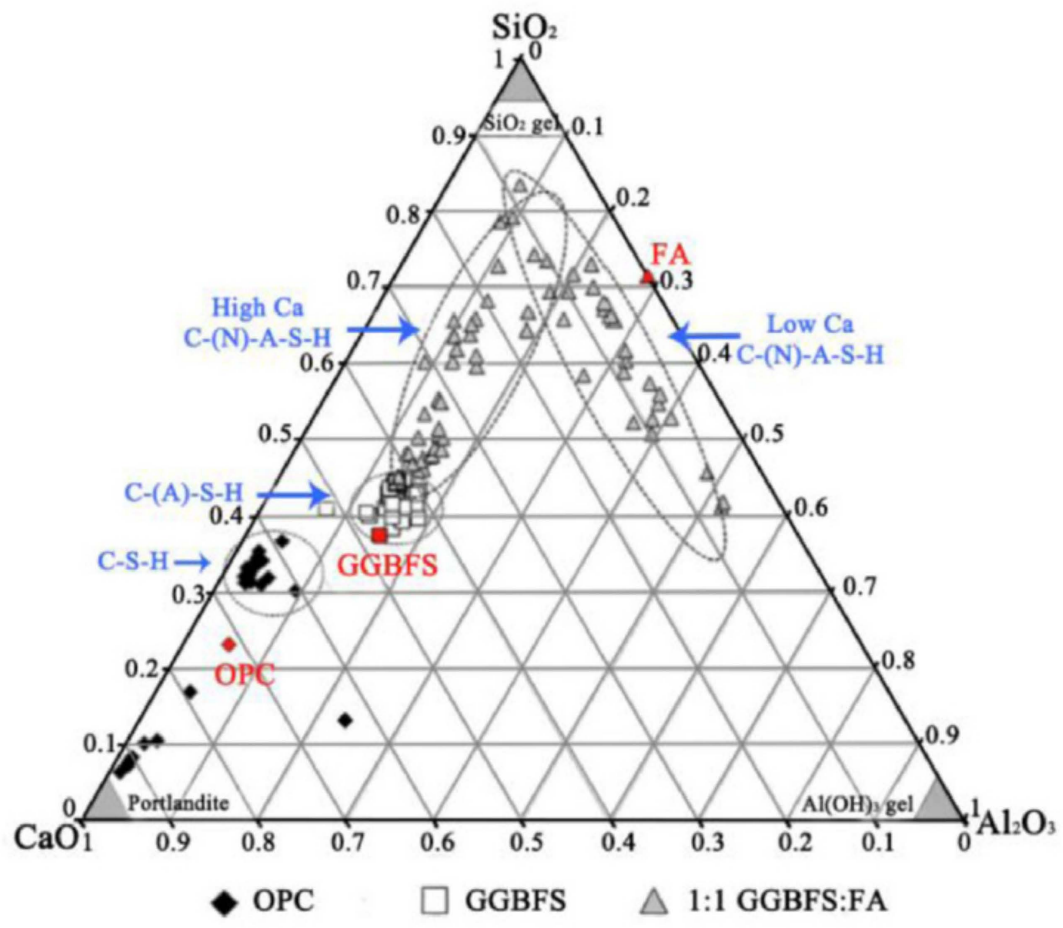

Figure 2. OPC and GPC composition of binder gel; reprinted with permission from [15].

When exposed to high temperatures during curing, FA-based GPC has shown exceptional mechanical characteristics and endurance. According to the literature, it is necessary to cure FA at a temperature between 60 and 85 degrees Celsius to activate it. This is because, at room temperature, FA reactivity is inadequate and alkaline activators are required [16]; in consequence, the testing specimens are filled with partially reacted gels during the reaction process preventing full polymerisation [17]. Using GGBFS under ambient temperature curing conditions, it was found that the characteristics of GPC made with FA could be improved, perhaps due to the presence of calcium oxide $(\mathrm{CaO})$ in the GGBFS [18]. As a result, the adoption of GPC made with FA/GGBFS may decrease energy consumption, emissions of $\mathrm{CO}_{2}$, and waste recovery while increasing efficiency. Additional advantages of GPC made with FA/GGBFS include its exceptional corrosion resistance [19], high-temperature resistance [20], freeze-thaw resistance [21], mechanical properties [22], and excellent properties of interfacial bonding, among other distinctive characteristics [23]. Several researchers have investigated GPC made with FA/GGBFS, which has been shown to have exceptional characteristics. Yet, there has been no single comprehensive evaluation of the fresh and hardened engineering properties, long-term durability, and applications of GPC made with FA/GGBFS. A detailed evaluation of GPC made with FA/GGBFS, when utilized to substitute for OPC concrete, is urgently needed to summarize essential information on its properties to encourage the use and future investigation of FA/GGBFS-based GPC.

\subsection{Geopolymer Reaction Mechanism}

The geopolymer is a 3D zeolite-like network structure made up of a tetrahedral aluminum-oxygen ( $\mathrm{Al}-\mathrm{O})$ and silicon-oxygen ( $\mathrm{Si}-\mathrm{O})$ [24]. Many investigations on the geopolymer's reaction mechanism have been conducted by dissolving aluminum and silicon components in a very alkaline environment [25]. The geopolymer reaction mechanisms depend on the preparation technique, the alkaline activator quantity, and the chemical composition of the raw components [26]. Due to the many elements in the fluid stage, all reactions proceed and influence each other concurrently [27]. Consequently, the mech- 
anisms of geological polymerization involve additional complexity to OPC hydration. Davidovits [24] proposed a structure for the geopolymer as expressed by Equation (1):

$$
\mathrm{Mn}\left[\left(\mathrm{SiO}_{2}\right)_{z}-\mathrm{AlO}_{2}\right]_{n} \cdot \mathrm{wH}_{2} \mathrm{O}
$$

where, $w$ is the quantity of chemical binding water molecules, $n$ is the degree of polycondensation, $M$ is the alkaline metal cation, and $z$ is the ratio $(1,2$, or 3$)$ of silicone to aluminum ( $\mathrm{Si} / \mathrm{Al})$. The structures of the geopolymer are divided into three types according to the $\mathrm{Z}$ value: silicon-aluminum $(\mathrm{Gel} 3, \mathrm{Si} / \mathrm{Al}=1)$, silicon-aluminum $(\mathrm{Gel} 2, \mathrm{Al}=2)$, and silicon-aluminum $(\mathrm{Gel} 1, \mathrm{Si} / \mathrm{Al}=3)$. These structures are shown in Figure 3.

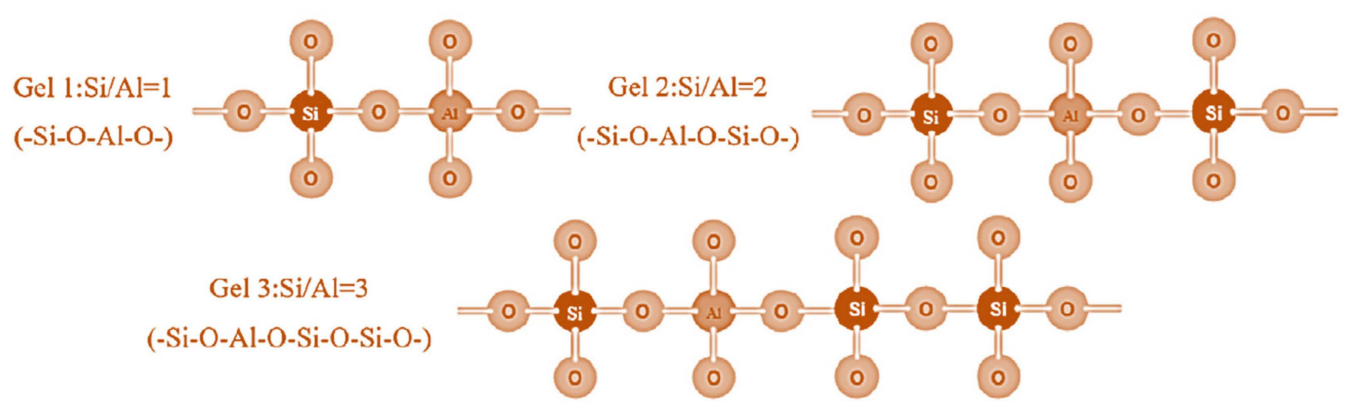

Figure 3. Geopolymer structure.

The hardening of geopolymer materials involves breaking and recombining the $\mathrm{Si}-\mathrm{O}$ and $\mathrm{Al}-\mathrm{O}$ bonds under the action of an alkaline activator [28]. The reaction process comprises four stages, as follows: (i) dissolution: the bonds of $\mathrm{Al}-\mathrm{O}$ and $\mathrm{Si}-\mathrm{O}$ are broken down into aluminum-silicate materials by an alkaline activator and the tetrahedral monomers $\mathrm{Al}-\mathrm{O}$ and $\mathrm{Si}-\mathrm{O}$ are unleashed; (ii) diffusion: the dissolved monomers of $\mathrm{Al}-\mathrm{O}$ and $\mathrm{Si}-\mathrm{O}$ spread to the system of reaction-the concept of chemical equilibrium implies that the concentration of aluminum and silicon on the surface particle decreases because of diffusion and the continued dissolution process; (iii) polycondensation: $\mathrm{Al}-\mathrm{O}$ and $\mathrm{Si}-\mathrm{O}$ tetrahedra, via polymerization, are amorphous $-\mathrm{Si}-\mathrm{O}-\mathrm{Al}-\mathrm{O}$ - structures; (iv) hardening: a process of dehydration happens that forms a hardened, mechanically high strength geopolymer. These stages occur concurrently; however, the first step of each reaction process is different. The polymerization processes are not the same for different raw materials used for the geopolymer, but they correspond to the above reaction procedure.

The conceptual model [29] shows that activated silico-aluminous cement components create geopolymers operated by alkaline activators. The processes of polymerization are divided into four categories by the model: deconstruction, gel formation, polycondensation, and crystallization. Paloma [29] proposed a model which includes five different types of reaction processes for the geopolymer. In contrast to the Davidovits model [24], the polycondensation process is divided into two stages: gelation and reconstitution. Gelation includes dehydration when the aluminosilicate is saturated to create a reconstituted oligomeric gel. The gel is dehydrated and condensed and eventually forms the geopolymer's threedimensional structure of a network. The geopolymer's function and water form are linked to the method of geopolymerisation that is performed. Qualitative investigation has shown that water is expelled throughout the reaction process [30]. Discontinuous nanopores are formed by the evaporation of water, which improved the performance of the geopolymer. Water, therefore, plays no part in the processes of chemical reactions and merely increases the functionality of the mixture during manufacturing. This contrasts with OPC hydration when water is involved in chemical reaction. Alongside the described models, several researchers have examined the geopolymer reaction mechanisms, such as alkaline activation [31], the effect of the sodium silicate/sodium hydroxide ratio [32], and the interfacial bonding mechanism between the geopolymer composite and fibres [33], which have contributed to the further understanding of the mechanism of geopolymer formation. 


\subsection{Probable Source Materials}

Table 1 summarizes the likely basic materials and additions for geopolymer concrete. Statistically, FA is the most often utilized raw material for geopolymer synthesis in the references mentioned in this article, followed by blast furnace slag (BFS), metakaolin (MK), and palm oil fuel ash (POFA). Additionally, many additional aluminosilicate materials are occasionally utilized, including bottom ash (BA), pozzolan, kaolin (KL), natural zeolites, granulated lead smelter slag (GLSS), rice husk ash (RHA), ultra-fine kaolite highperformance ash (HFA), and biomass fly ash (BFA). In addition to these raw ingredients, a variety of supplements are utilized.

FA is the most significant by-product produced by thermal power plants and is discharged into the environment. With the expansion of the electric power sector, the FA discharge from coal-fired power plants has steadily increased in volume. It has now surpassed all other industrial waste leftovers to become one of the world's largest industrial waste products. FA contains more than $60 \%$ aluminum oxides and silicon and has an $88 \%$ pozzolanic activity index [1]. As a result, it is very simple to hydrate under alkaline activation. Consequently, FA has become the most significant and extensively used raw ingredient in the manufacture of geopolymer concrete. Furthermore, FA was utilized as the basis for the majority of research performed before 2014 [34]. Kupaei et al. [35] reported the compressive strength for a low-calcium lightweight geopolymer made with FA and composed of coarse aggregates derived from oil palm shells. Compressive strength reduced when the ratio of sand to binder was kept constant as the water to FA ratio increased; sufficient water was required to guarantee workability. As a result, the author recommended $480 \mathrm{~kg} / \mathrm{m}^{3}$ of FA and a water to FA ratio of 0.34 for producing geopolymer concrete of grade 30. In addition, Diaz-Loya et al. [36] established a novel relationship between FA fineness and GPC density described by equation [37].

Table 1. Major source materials of aluminosilicate.

\begin{tabular}{|c|c|c|c|c|}
\hline Type & Item & Acronym & Reference & Constituents \\
\hline \multirow{12}{*}{ Source material } & Pozzolana blast furnace slag & BFS & {$[37-41]$} & \multirow{17}{*}{$\begin{array}{c}\mathrm{SiO}_{2} \\
\mathrm{Al}_{2} \mathrm{O}_{3} \\
\mathrm{Fe}_{2} \mathrm{O}_{3} \\
\mathrm{CaO} \\
\mathrm{P}_{2} \mathrm{O}_{5} \\
\mathrm{Na}_{2} \mathrm{O} \\
\mathrm{K}_{2} \mathrm{O} \\
\mathrm{MnO} \\
\mathrm{MgO} \\
\mathrm{SO}_{3} \\
\mathrm{TiO}_{2}\end{array}$} \\
\hline & Metakaolin & MK & [42-45] & \\
\hline & Bottom ash & $\mathrm{BA}$ & [46-48] & \\
\hline & Fly ash & FA & {$[13,49-54]$} & \\
\hline & Silico-manganese fume & SMF & [55] & \\
\hline & Biomass fly ash & BFA & {$[56,57]$} & \\
\hline & $\begin{array}{l}\text { Ultra fine kaolite high } \\
\text { performance ash }\end{array}$ & HFA & {$[58,59]$} & \\
\hline & Ferrochrome slag & FS & [60] & \\
\hline & Rice husk ash & RHA & {$[43,61,62]$} & \\
\hline & Granulated lead smelter slag & GLSS & {$[63,64]$} & \\
\hline & Palm oil fuel ash & POFA & {$[19,65-67]$} & \\
\hline & Natural zeolites kaolin & KL & {$[68,69]$} & \\
\hline \multirow{5}{*}{ Additives } & Silica fume & SF & {$[50,70]$} & \\
\hline & Ordinary Portland cement & OPC & [71-73] & \\
\hline & Calcium hydroxide & $\mathrm{Ca}(\mathrm{OH})_{2}$ & [46] & \\
\hline & Nano-silica & & [74] & \\
\hline & Calcium aluminate cement & CAC & [75] & \\
\hline
\end{tabular}

Recently, many new kinds of silicon-aluminum compounds have received much interest. These include POFA alloys, MK and BFS, which were introduced in 2014. In the early 2000s, several researchers began investigating the impact of various blends of source materials on geopolymer concrete's physical or mechanical characteristics. Khan et al. [59] developed cast-in-place OPC concrete and geopolymer concretes including BFS, kaolite HPA, and blended FA. In addition to testing the workability of new concrete, they also examined the mechanical characteristics of hardened concrete. Using equal binders in both geopolymer and cement concrete resulted in slower contraction of geopolymer concrete 
than cement concrete. Using steel furnace slag as the coarse aggregate, the findings indicated that geopolymer was better than cement for producing stronger concrete. This is because geopolymer has greater compatibility with aggregates compared to cement. Xie and Ozbakkaloglu [47] showed that greater FA concentration in the binder resulted in improved coal-ash-based geopolymer concrete workability compared to other binder types. A closely similar result was obtained by Hadi et al. [76], who found that including a small quantity of FA into a BFS-based binder may enhance the fresh geopolymer concrete workability when it is mixed at room temperature. In addition, in recent years, zeolites have been utilized as a raw material for producing geopolymer concrete, as reported by Ozen and Alam [77] and by Xu et al. [78]. The researchers at Karthik et al. [39] performed tests on the beneficial effects of bio-additives on the durability of BFS-based geopolymer concrete, in addition to the usual silicon-aluminum-based materials. Two kinds of bio-additives were used in the research: terminalia chebula and natural sugars (molasses, palm jaggery, and honey). The findings were that the FA/BFS-based geopolymer concrete, including bioadditives, had a dense microstructure and was more durable than conventional geopolymer concrete compared to the control. Similarly, Assi et al. [79] utilized sucrose to decrease the number of porous holes in geopolymer concrete, with promising results. Although several studies are available for GPC, there is a major research gap regarding how the best mixing combinations and optimal conditions may be achieved with minimal experimental trials. The Taguchi method was used to reduce the number of experiments and find the optimum mixing combination to produce higher compressive strength to fill this research gap.

\section{Research Significance}

In the available bibliographies of resources, there is a lack of sufficient information about the optimum mixing combination of GPC, particularly with FA, GGBFS, and silica fume (SF). Several researchers across the world have used a variety of industrial byproducts to produce GPC considering single or multiple factors. The consideration of several factors, such as varying binder content, different molarity, different superplasticizer dosage, and different $\mathrm{Na}_{2} \mathrm{SiO}_{3} / \mathrm{NaOH}$ ratios, to achieve a reasonable conclusion is worthwhile. However, only a few studies have been conducted to optimize the GPC mixture with different combinations of materials used for the binder. There are still gaps in this research area. This study attempted to optimize the GPC mixtures to attain higher compressive strength to close these research gaps. In this research, the Taguchi approach was employed considering four factors and four levels including: four binder combinations of FA and GGFBS, four dosages of superplasticizer $(0.5,1.0,1.5$ and $2 \%)$, four $\mathrm{Na}_{2} \mathrm{SiO}_{3} / \mathrm{NaOH}$ ratios $(1.5,2.0,2.5$ and 3$)$, and four molarities $(6,8,10$ and 12$)$.

\section{Experimental Methods}

\subsection{Raw Materials}

Material for the binder consisted of Class F fly ash (FA) procured from Neyveli Lignite Corporation in accordance with the requirements of ASTM C618-08 [80]. A combination of the FA, GGBFS, and SF was used to produce GPC and specimens were cured at room temperature. Earlier studies have reported that the polymerization process was accelerated according to GGBFS and $\mathrm{CaO}$ content. At the same time, silica fumes with smaller particle size may react faster with an alkaline solution, resulting in the formation of a denser matrix [29]. Astra Chemicals Chennai provided the GGBFS, SF, and alkali solutions. The chemical composition of the SF, GGBFS, and FA are shown in Table 2. According to the requirements of IS 383 [81], natural river sand was utilized as the fine aggregate with a fineness modulus of 2.41 and a specific gravity of 2.65. The fine aggregate particle size was less than $2.36 \mathrm{~mm}$. According to IS 383 [81], coarse aggregate made from crushed granite gravel with a size of 12.5 and $20 \mathrm{~mm}$ was used with percentage content of 60 and 40 , respectively. The coarse aggregate had a water absorption of $0.56 \%$, a specific gravity of 2.69, and an apparent bulk density of $1700 \mathrm{~kg} / \mathrm{m}^{3}$. Tech Mix 550 high range super plasticizing additive was used with four-doses of $0.5,1.0,1.5$, and 2.0 by binder 
weight. Additionally, to activate the pozzolanic binders, an amalgamation of $\mathrm{Na}_{2} \mathrm{SiO}_{3}$ and $\mathrm{NaOH}$ pellets was used. In order to prepare an alkaline solution, sodium hydroxide pellets were dissolved in distilled water to the required molar content, followed by the addition of sodium silicate to form an alkaline solution with sodium hydroxide pellets. The solution was prepared approximately one day prior to the casting of the specimens. The raw materials used to produce the GPC are shown in Figure 4.

Table 2. Chemical composition of binders.

\begin{tabular}{cccc}
\hline Oxide & Class F FA & GGBFS & SF \\
\hline Titanium Dioxide $\left(\mathrm{TiO}_{2}\right)$ & 0.1 & - & - \\
Sodium Oxide $\left(\mathrm{Na}_{2} \mathrm{O}\right)$ & 0.2 & - & - \\
Potassium Oxide $\left(\mathrm{K}_{2} \mathrm{O}\right)$ & 1.6 & - & - \\
Magnesium Oxide $(\mathrm{MgO})$ & 5.9 & 8.9 & 0.6 \\
Calcium Oxide $(\mathrm{CaO})$ & 6.4 & 34.62 & - \\
Ferric Oxide $\left(\mathrm{Fe}_{2} \mathrm{O}_{3}\right)$ & 12 & 1 & 0.3 \\
Alumina $\left(\mathrm{Al}_{2} \mathrm{O}_{3}\right)$ & 27 & 17.2 & 0.6 \\
Silica $\left(\mathrm{SiO}_{2}\right)$ & 51 & 36.7 & 92.8 \\
\hline
\end{tabular}
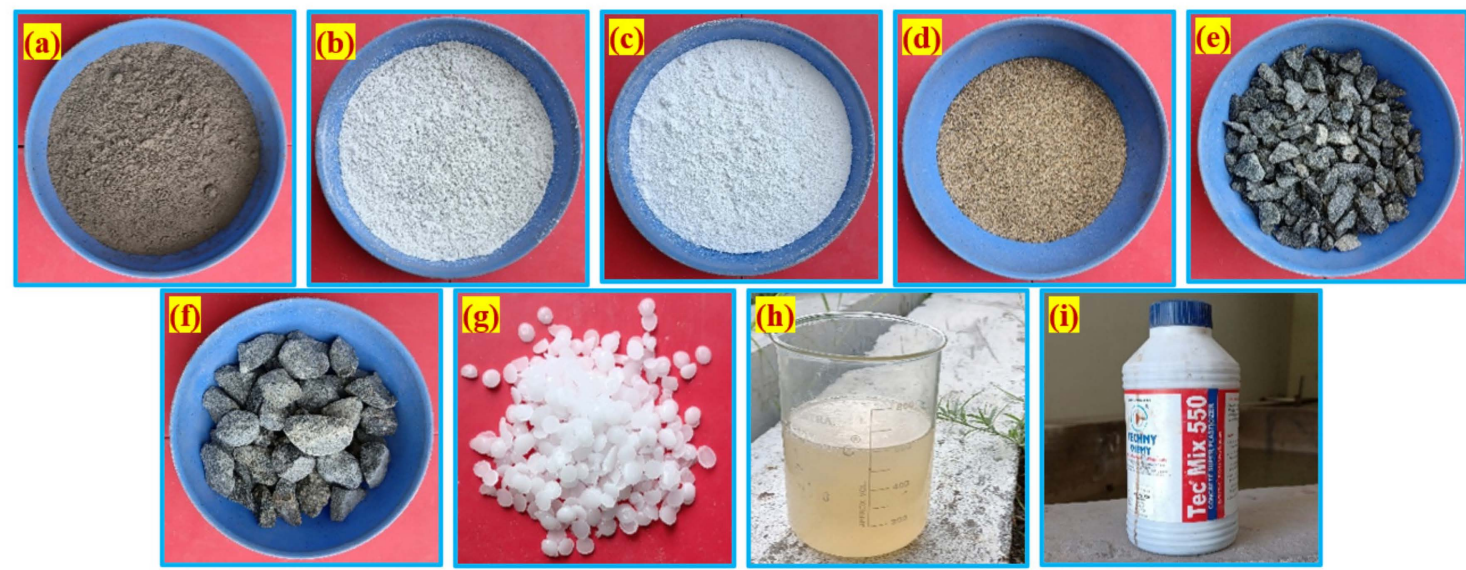

Figure 4. Raw materials used in this research: (a) fly ash, (b) GGBFS, (c) silica fume, (d) fine aggregate, (e) coarse aggregate $12.5 \mathrm{~mm}$, (f) coarse aggregate $20 \mathrm{~mm}$, (g) sodium hydroxide flakes, (h) sodium silicate solution, (i) superplasticizer.

\subsection{Mix Design Preparation Using the Taguchi Method Orthogonal Array}

In a parameter design experiment, the goal is to find and design the configurations of the input parameters that optimize a selected quality characteristic while being the least sensitive. For situations where many factors need to be considered, the Taguchi approach is a systematic strategy to determine the "best" set of parameters to make a product with optimum characteristics. Several factors can be studied with a minimum number of experiments using orthogonal arrays with the Taguchi technique. Orthogonal arrays significantly reduce the number of research procedures that must be investigated. In addition, the key findings from small-scale experimentation are applicable across a wide experimental range. ANOVA was used to analyze the experimental results to find the contribution of each independent variable on the compressive strength of the GPC. ANOVA is a fundamental statistical approach for quantitatively estimating each variable's relative contribution to the considered response and expressing this contribution as a percentage of the total measured response. It is the ratio of the sum of squares of each factor to the total sum of squares representing each factor's percentage contribution. The factors that were chosen for examination were as follows: (i) binders comprising a different percentage of FA and GGBFS and named as $\mathrm{B} 1=60 \% \mathrm{FA}+30 \% \mathrm{GGBFS}+10 \% \mathrm{SF}, \mathrm{B} 2=55 \% \mathrm{FA}+35 \% \mathrm{GGBFS}+10 \% \mathrm{SF}, \mathrm{B} 3=50 \%$ $\mathrm{FA}+40 \% \mathrm{GGBFS}+10 \% \mathrm{SF}$, and $\mathrm{B} 4=45 \% \mathrm{FA}+45 \% \mathrm{GGBFS}+10 \% \mathrm{SF}$, (ii) dosage of superplasticizer (0.5, 1.0, 1.5, and 2.0\%), (iii) $\mathrm{Na}_{2} \mathrm{SiO}_{3} / \mathrm{NaOH}$ ratio (1.5, 2.0, 2.5, and 3.0), and 
(iv) molar ratio $(6,8,10$, and 12$)$ in the alkaline solution. The design of experiments with four factors and four levels is presented in Table 3. Consistent with the L16 (44) orthogonal array Taguchi design, only 16 experiments were required for the investigation (Table 4.)

Table 3. Experimental factors and the various levels.

\begin{tabular}{lcccc}
\hline \multicolumn{1}{c}{ Factor } & Level 1 & Level 2 & Level 3 & Level 4 \\
\hline A. Binder content & $\mathrm{B} 1$ & $\mathrm{~B} 2$ & $\mathrm{~B} 3$ & $\mathrm{~B} 4$ \\
B. Dosage of superplasticizer $(\%)$ & 0.5 & 1.0 & 1.5 & 2.0 \\
$\mathrm{C} . \mathrm{Na}_{2} \mathrm{SiO}_{3} / \mathrm{NaOH}$ ratio & 1.5 & 2 & 2.5 & 3 \\
D. Molar content & 6 & 8 & 10 & 12 \\
\hline
\end{tabular}

Table 4. (L16) orthogonal array.

\begin{tabular}{ccccc}
\hline Experiment No. & A & B & C & D \\
\hline 1 & 1 & 1 & 1 & 1 \\
2 & 1 & 2 & 2 & 2 \\
3 & 1 & 3 & 3 & 3 \\
4 & 1 & 4 & 4 & 4 \\
5 & 2 & 1 & 2 & 3 \\
6 & 2 & 2 & 1 & 4 \\
7 & 2 & 3 & 4 & 1 \\
8 & 2 & 3 & 2 \\
9 & 3 & 1 & 3 & 4 \\
10 & 3 & 2 & 4 & 3 \\
11 & 3 & 3 & 2 & 1 \\
12 & 3 & 4 & 4 & 2 \\
13 & 4 & 1 & 3 & 1 \\
14 & 4 & 2 & 2 & 4 \\
15 & 4 & 3 & 1 & 3 \\
16 & 4 & 4 & & \\
\hline
\end{tabular}

\subsection{Mixing Combination, Mixing Procedure}

The mixing combination of the FA, GGBFS, SF, fine and coarse aggregate used in this research is shown in Table 5. The selection of these materials and quantities were based on several trials to ensure a compressive strength greater than $30 \mathrm{MPa}$. The casting procedure for the GPC consisted of the following steps: first, the dry materials including FA, GGBFS, SF, and fine aggregate were mixed for $3 \mathrm{~min}$. Then coarse aggregates were added and allowed to mix for another $3 \mathrm{~min}$. After this process, water, sodium silicate, sodium hydroxide solution, and superplasticizer were mixed thoroughly and added into a dry mixture and mixed for $3 \mathrm{~min}$ to achieve a homogeneous mixture. The appearance of the GPC mixture as shown in Figure 5 and the corresponding workability of these mixture were very stiff. The GPC mixture was moulded into a cube of $100 \mathrm{~mm}$ in size and vibration was applied to achieve a uniform concrete mixture. The filled moulds were then allowed to cure at room temperature ( 24 degrees Celsius and 20 percent relative humidity), with the top surface of the mould exposure to the ambient air temperature during the curing procedure. The specimens were demoulded after $24 \mathrm{~h}$, and they were allowed to cure at room temperature until the day of testing (28 days), as shown in Figure 5. 
Table 5. Mixing proportions.

\begin{tabular}{|c|c|c|c|c|c|c|c|c|c|c|c|}
\hline $\begin{array}{l}\text { Exp } \\
\text { No. }\end{array}$ & $\mathbf{A}$ & B & $\mathrm{C}$ & D & $\begin{array}{l}\text { Fly Ash } \\
\left(\mathrm{kg} / \mathrm{m}^{3}\right)\end{array}$ & $\begin{array}{l}\text { GGBFS } \\
\left(\mathrm{kg} / \mathrm{m}^{3}\right)\end{array}$ & $\begin{array}{c}\mathrm{SF} \\
\left(\mathrm{kg} / \mathrm{m}^{3}\right)\end{array}$ & $\begin{array}{c}\text { Fine } \\
\text { Aggregate } \\
\left(\mathrm{kg} / \mathrm{m}^{3}\right)\end{array}$ & $\begin{array}{c}\text { Coarse } \\
\text { Aggregate } \\
\left(\mathrm{kg} / \mathrm{m}^{3}\right)\end{array}$ & $\begin{array}{l}\mathrm{Na}_{2} \mathrm{SiO}_{3} \\
\left(\mathrm{~kg} / \mathrm{m}^{3}\right)\end{array}$ & $\begin{array}{c}\mathrm{NaOH} \\
\left(\mathrm{kg} / \mathrm{m}^{3}\right)\end{array}$ \\
\hline 1 & B1 & 0.5 & 1.5 & 6 & 244.80 & 122.40 & 40.8 & \multirow{16}{*}{554.4} & \multirow{16}{*}{1293.6} & 101.39 & 69.93 \\
\hline 2 & B2 & 1 & 2 & 8 & 224.40 & 142.80 & 40.8 & & & 113.25 & 58.07 \\
\hline 3 & B3 & 1.5 & 2.5 & 10 & 204.00 & 163.20 & 40.8 & & & 121.66 & 49.66 \\
\hline 4 & B4 & 2 & 3 & 12 & 183.60 & 183.60 & 40.8 & & & 127.95 & 43.37 \\
\hline 5 & B2 & 0.5 & 2 & 10 & 224.40 & 142.80 & 40.8 & & & 113.25 & 58.07 \\
\hline 6 & B2 & 1 & 1.5 & 12 & 224.40 & 142.80 & 40.8 & & & 101.39 & 69.93 \\
\hline 7 & B2 & 1.5 & 3 & 6 & 224.40 & 142.80 & 40.8 & & & 127.95 & 43.37 \\
\hline 8 & B2 & 2 & 2.5 & 8 & 224.40 & 142.80 & 40.8 & & & 121.66 & 49.66 \\
\hline 9 & B3 & 0.5 & 2.5 & 12 & 204.00 & 163.20 & 40.8 & & & 121.66 & 49.66 \\
\hline 10 & B3 & 1 & 3 & 10 & 204.00 & 163.20 & 40.8 & & & 127.95 & 43.37 \\
\hline 11 & B3 & 1.5 & 1.5 & 8 & 204.00 & 163.20 & 40.8 & & & 101.39 & 69.93 \\
\hline 12 & B3 & 2 & 2 & 6 & 204.00 & 163.20 & 40.8 & & & 113.25 & 58.07 \\
\hline 13 & B4 & 0.5 & 3 & 8 & 183.60 & 183.60 & 40.8 & & & 127.95 & 43.37 \\
\hline 14 & B4 & 1 & 2.5 & 6 & 183.60 & 183.60 & 40.8 & & & 121.66 & 49.66 \\
\hline 15 & B4 & 1.5 & 2 & 12 & 183.60 & 183.60 & 40.8 & & & 113.25 & 58.07 \\
\hline 16 & B4 & 2 & 1.5 & 10 & 183.60 & 183.60 & 40.8 & & & 101.39 & 69.93 \\
\hline
\end{tabular}

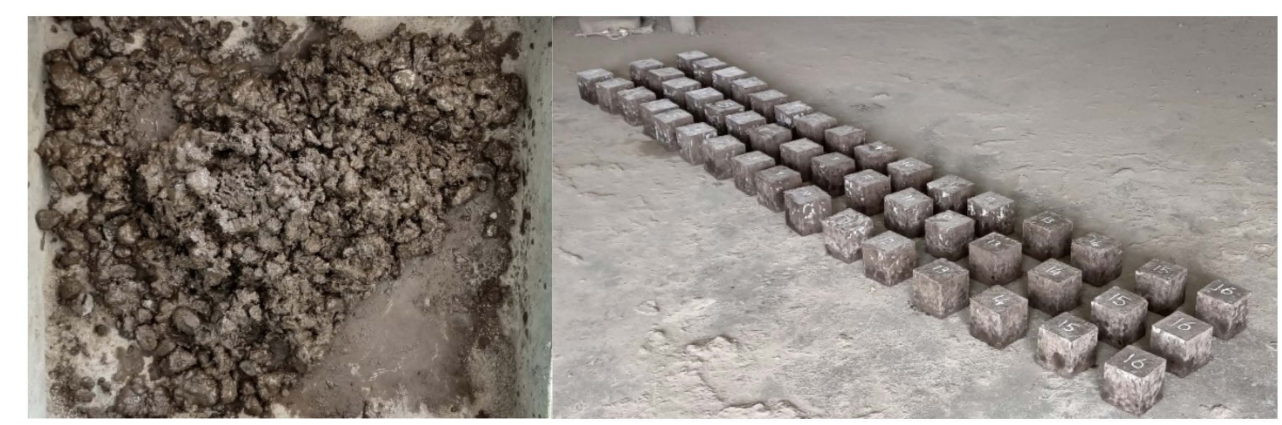

Figure 5. GPC mixture and specimens after demoulding.

\subsection{Testing Methodology}

A compressive strength test was employed on $100 \mathrm{~mm}$ cubes using the $300 \mathrm{~T}$ capacity of a compression testing machine supplied by Aimil Ltd., Delhi, India. Three specimens were cast for each mixture and tested according to IS 516 [82]. The compression testing machine used in this study is shown in Figure 6. 


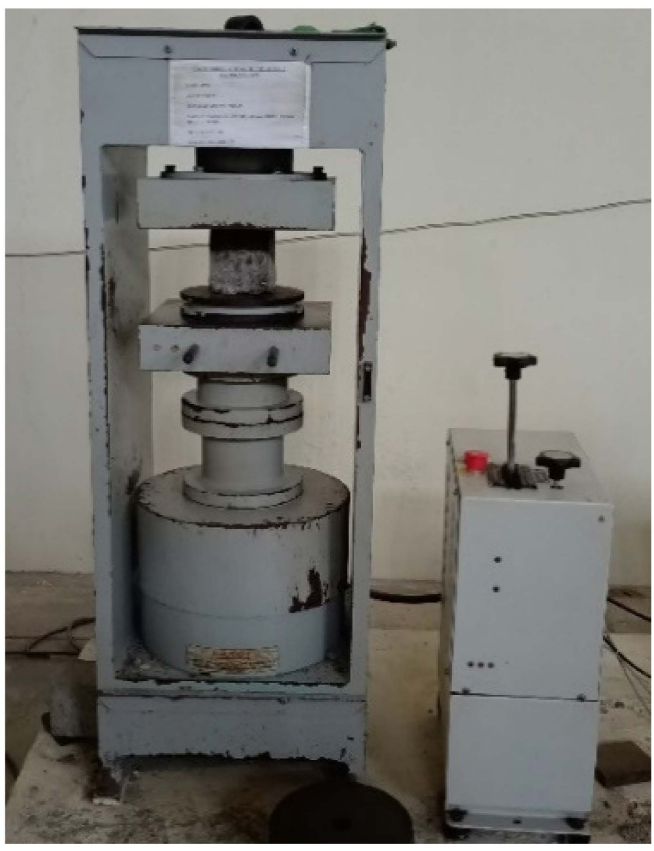

Figure 6. Compression testing machine.

\section{Discussion of Results}

It can be seen in Table 6 that the Taguchi model was used to determine the GPC's optimum compressive strength and the parameters associated with it. Three specimens were developed and tested against compression in each experiment. In the scientific literature, conventionally an average of three specimens is used to determine the compressive strength of concrete. When more than one result of a single specimen deviates by more than $10 \%$ from the mean, the results should be discarded. A new set of specimens should be fabricated to ensure that the results are satisfactory in the future.

Table 6. Compressive strength results.

\begin{tabular}{cccccc}
\hline \multirow{2}{*}{ Trials } & \multicolumn{4}{c}{ Compressive Strength (MPa) } & $\begin{array}{c}\text { Standard } \\
\text { Deviation }\end{array}$ \\
\cline { 2 - 6 } & $\mathbf{1}$ & $\mathbf{2}$ & $\mathbf{3}$ & Average & 1.99 \\
\hline TR1 & 27.3 & 30.3 & 31.1 & 29.6 & 2.73 \\
\hline TR2 & 32.8 & 30.8 & 27.4 & 30.3 & 1.59 \\
\hline TR3 & 37.5 & 34.4 & 35.2 & 35.7 & 2.00 \\
\hline TR4 & 30.9 & 34.9 & 32.8 & 32.9 & 3.05 \\
\hline TR5 & 35.2 & 38.1 & 41.3 & 38.2 & 1.88 \\
\hline TR6 & 37.4 & 35.6 & 33.6 & 35.5 & 2.65 \\
\hline TR7 & 35.1 & 37.9 & 40.4 & 37.8 & 2.02 \\
\hline TR8 & 33.6 & 29.6 & 31.1 & 31.4 & 3.11 \\
\hline TR9 & 36.1 & 42.3 & 38.5 & 39.0 & 0.76 \\
\hline TR10 & 29.1 & 29.7 & 28.2 & 29.0 & 2.19 \\
\hline TR11 & 41.8 & 44.6 & 40.3 & 42.2 & 4.68 \\
\hline TR12 & 31.8 & 39.1 & 40.5 & 37.2 & 2.57 \\
\hline TR13 & 38.2 & 35.7 & 40.8 & 38.2 & 1.88 \\
\hline TR14 & 36.9 & 38.2 & 34.5 & 36.5 & 1.05 \\
\hline TR15 & 38.2 & 37.1 & 39.2 & 38.2 & 2.11 \\
\hline TR16 & 41.3 & 43.8 & 39.6 & 41.6 & \\
\hline & & & & & \\
\hline
\end{tabular}


The influence of each factor on the development of compressive strength is shown in Figure 7, which was created by analyzing the data in Table 1 and drawing conclusions from them. The compressive strength of factor 1, level 1 (B1) was calculated as $(29.6+30.3+35.7+32.9) / 4$. According to the results, the binder, which was composed of different amounts of FA and GGBFS, appeared to have the greatest influence on compressive strength development. The highest compressive strength, $42.2 \mathrm{MPa}$, was observed in trial mix 11, as shown in Table 6, while trial mix 10 showed a minimum compressive strength of 29.0 MPa. The parameter that was most influential was binder content. The B4 binder showed the best test results. The inclusion of higher GGBFS content improved the strength of the concrete significantly. However, the compressive strength was less affected by the $\mathrm{Na}_{2} \mathrm{SiO}_{3} / \mathrm{NaOH}$ ratio. The $1.5 \%$ dosage of superplasticizer and 1.5 ratio of $\mathrm{Na}_{2} \mathrm{SiO}_{3} / \mathrm{NaOH}$ showed better compressive strength results. More superplasticizer can obstruct the polymerization process by forming a thin layer over binder particles which slow down the poly-condensation process and leave only a few unreacted particles. The effects of individual factors, their levels in relation to other factors, and their variations on GPC compressive strength are shown in Figure 7a-d. The highest compressive strength from the factor 1 (binder), which was exhibited by the B4 binder, comprised 45\% FA, 45\% GGBFS, and $10 \%$ SF. The reason for this behaviour was that a higher CaO content in GGBFS speeds up polymerization due to the heat released and aids in forming an improved polymeric chain and progressive development of $\mathrm{C}-\mathrm{S}-\mathrm{H}, \mathrm{N}-\mathrm{S}-\mathrm{H}$, and $\mathrm{N}-\mathrm{A}-\mathrm{S}-\mathrm{H}$ gels. Increasing the GGBFS contents from the B1 to B4 binders resulted in increasing the compressive strength.
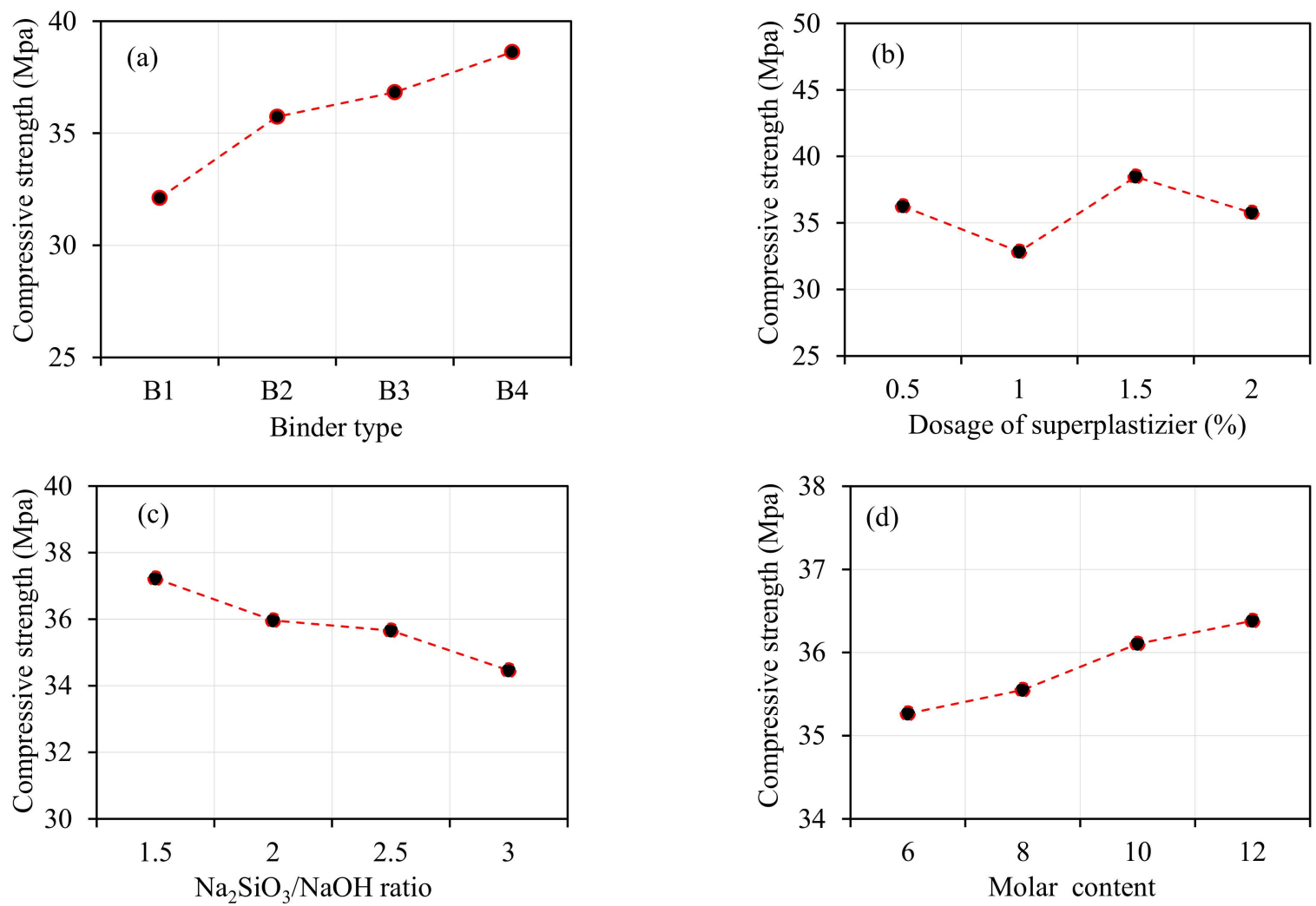

Figure 7. The influence of the investigated parameters on the compressive strength development. (a) Binder type; (b) Dosage of superplasticizer (\%); (c) $\mathrm{Na}_{2} \mathrm{SiO}_{3} / \mathrm{NaOH}$ ratio and (d) Molar content.

The influence of the superplasticizer dosage on the compressive strength is shown in Figure $7 \mathrm{~b}$. The compressive strength of factor 2, level 1, was calculated as $(29.6+38.2+39.0+38.2) / 4$. In a similar way, the compressive strength of other levels was calculated with the corresponding values for the levels. For this factor, the highest compressive strength was exhibited by the $1.5 \%$ dosage of superplasticizer. 
The influence of a 0.5 and $2.0 \%$ dosage of superplasticizer showed only marginal differences in compressive strength. However, a 1.0\% dosage of superplasticizer exhibited a lower compressive strength. In general, increasing the content of the superplasticizer lead to a slight decrease in strength [83]. However, in this study, the usage of Tech Mix 640 commercialized superplasticizers with a 1.5 dosage was more effective when used with the binders comprising FA, GGBFS, and SF.

Figure 7c illustrates the influence of the $\mathrm{Na}_{2} \mathrm{SiO}_{3} / \mathrm{NaOH}$ ratio on the compressive strength of GPC. It can be seen from Figure 7c that the highest compressive strength of GPC was exhibited with a $\mathrm{Na}_{2} \mathrm{SiO}_{3} / \mathrm{NaOH}$ ratio of 1.5. The compressive strength was decreased when the ratio of $\mathrm{Na}_{2} \mathrm{SiO}_{3} / \mathrm{NaOH}$ was increased from 1.5 to 3 . An earlier study reported that the ratio of $\mathrm{Na}_{2} \mathrm{SiO}_{3} / \mathrm{NaOH}=1$ lead to attaining a maximum compressive strength of GPC. An increase in the ratio of $\mathrm{Na}_{2} \mathrm{SiO}_{3} / \mathrm{NaOH}$ from 1 to 2.5 resulted in a decrease in compressive strength [84]. A further finding was that when the mass ratio of $\mathrm{Na}_{2} \mathrm{SiO}_{3} / \mathrm{NaOH}$ was the same, the dissolution of silica and alumina was high, increasing the compressive strength of fly-ash-based GPC [84]. In this study, the ratios of $\mathrm{Na}_{2} \mathrm{SiO}_{3} / \mathrm{NaOH}$ selected were 1.5, 2.0, 2.5, and 3.0. The $\mathrm{Na}_{2} \mathrm{SiO}_{3} / \mathrm{NaOH}$ ratio $=1.5$ displayed the highest compressive strength of GPC; this trend aligns with an earlier study [84]. Broadly, a rise in the ratio of $\mathrm{Na}_{2} \mathrm{SiO}_{3} / \mathrm{NaOH}$ resulted in a rise in the amount of sodium in the concrete mixture. Sodium is crucial for producing geopolymers because it acts as a charge-balancing ion, which is essential for the formation of polymers. On the other hand, the compressive strength decreased as more sodium silicate was introduced into the system because excess sodium silicate interferes with the evaporation of water and structure formation [85].

The influence of molar content on the compressive strength of GPC is shown in Figure $7 \mathrm{~d}$. The influence of factors and level on compressive strength are shown in Figure 8. Four different molar contents were used in this study: 6, 8, 10, and 12 . The 12 molar content GPC exhibited the highest compressive strength. An increasing compressive strength trend was observed with increasing molar content from 6 to 12. This implies that, in this case, the widely accepted adage, "higher molar content equals greater compressive strength", remains true. However, when the $\mathrm{NaOH}$ was increased above 16-molar concentration, the compressive strength decreased. This was due to the high concentration of $\mathrm{NaOH}$ (hydroxide ions) in the solution, which caused the quick and early precipitation of aluminosilicate gel, which solidified quickly, hindering the forming of other geopolymeric precursors in the solution. Table 6 shows that the higher molar content lead to improvement in compression strength. This phenomenon was due to the reaction between $\mathrm{OH}$ ions and binders and generated surplus polymer gel. In sum, the optimum compressive strength of GPC was produced by a B4 binder comprised of $45 \% \mathrm{FA}, 45 \% \mathrm{GGBFS}$, and $10 \% \mathrm{SF}$, a $1.5 \%$ dosage of superplasticizer, a $\mathrm{Na}_{2} \mathrm{SiO}_{3} / \mathrm{NaOH}$ ratio $=1.5$, and 12 molar concentration.

An analysis of variance (ANOVA) was carried out to determine the quantitative influence of each factor on compressive strength development. Table 7 shows the percentage of influence exerted by each examined factor and the contribution of each factor's sum of squares to the total sum of squares. 

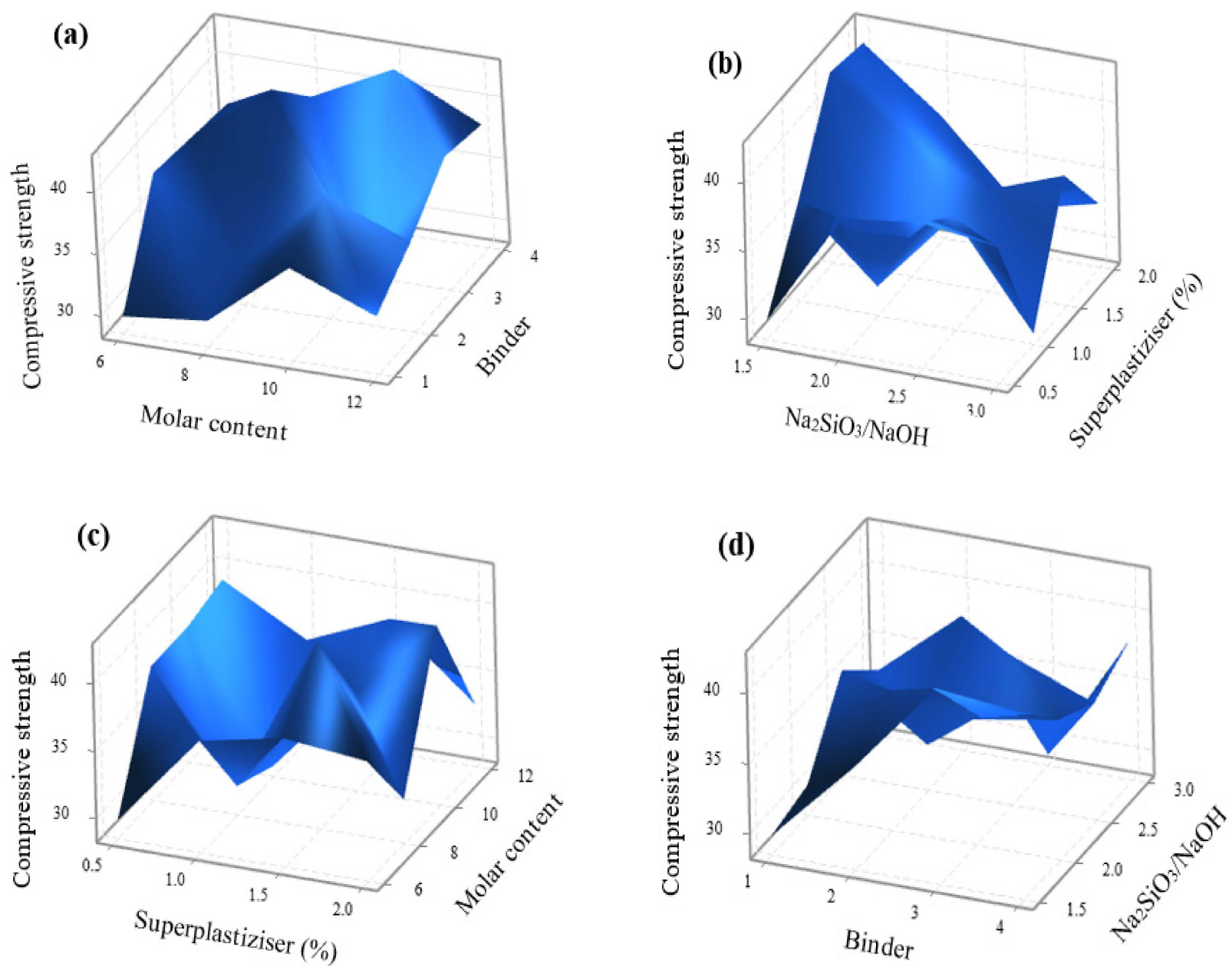

Figure 8. Influence of factors and level on compressive strength (MPa): (a) effect of molar content and binder, (b) effect of superplasticizer and $\mathrm{Na}_{2} \mathrm{SiO}_{3} / \mathrm{NaOH}$ ratio, (c) effect of molar content and superplasticizer, (d) effect of binder and $\mathrm{Na}_{2} \mathrm{SiO}_{3} / \mathrm{NaOH}$ ratio.

Table 7. The sum of squares and contribution of each factor on compressive strength.

\begin{tabular}{ccccc}
\hline Parameter & A & B & C & D \\
\hline SS & 271 & 193 & 46 & 9.29 \\
\hline Sum & & 520 & & \\
\hline Contribution & 52.16 & 37.17 & 8.89 & 1.79 \\
\hline
\end{tabular}

For example, the sum of squares $(S S)$ of the factor (Binder) is:

$$
S S=N \times L \times \sum_{i=1}^{L}\left(\bar{X}-X_{i}\right)^{2}
$$

where:

$S S$ : compressive strength is calculated using the sum of squares.

$N$ : every test requires a different sample number. $(N=3)$

$L$ : every factor has a set of level numbers $(L=4)$

$X_{i}$ : level $i$ mean strength (mean of $4 \times 4=16$ values)

$\bar{X}=$ the average strength of the experiments (average of $16 \times 3=48$ values)

For example, from Equation (2) SS of the factor (binder) for compression strength were determined, and the results are listed in the table below: 


$$
S S_{1}=3 \times 4 \times\left[(35.83-32.11)^{2}+(35.83-35.74)^{2}+(35.83-36.83)^{2}+(35.83-38.62)^{2}\right]=271
$$

Table 6 shows an example of an influencing parameter based on the analysis of variance outcomes. It should be emphasised that the binder is the most influencing factor, accounting for $52.16 \%$ of the total influence on compressive strength. In compressive strength, the second, third, and fourth most important parameters were the dosage of superplasticizer, the $\mathrm{Na}_{2} \mathrm{SiO}_{3} / \mathrm{NaOH}$ ratio, and molar content, which were $37.217 \%, 8.89 \%$, and $1.79 \%$, respectively. Among the control factors, the binder parameter was of greatest significance due to its high level of influence over the other variables.

\section{Conclusions}

The following are the main findings of the experimental and computational assessment of design mixes for GPC.

The design mix including a B4 binder comprised of 45\% FA, 45\% GGBFS, and 10\% SF, a $1.5 \%$ dosage of superplasticizer, $\mathrm{a} \mathrm{Na}_{2} \mathrm{SiO}_{3} / \mathrm{NaOH}$ ratio $=1.5$, and 12 molar content exhibited the best compressive strength. The proposed Taguchi approach to mix design to achieve the target strength of more than $25 \mathrm{~N} / \mathrm{mm}^{2}$ is suitable for urban constructions in developing countries such as India. For predicting the optimal mixture of constituents capable of providing the target strength of the GPC mix, the Taguchi method's L9 orthogonal array was found to be effective and accurate, minimizing a need to prepare many trial-mixes in the process. Nevertheless, in further research, the addition of factors with varying levels of importance is recommended for the design strength of the GPC combinations. As a result of the research, the importance of the components in the optimization approach, such as binder combinations, $\mathrm{Na}_{2} \mathrm{SiO}_{3} / \mathrm{NaOH}$ ratios, superplasticizer dosages, and the molar concentration of $\mathrm{NaOH}$ in the mix, for achieving target strength in accordance with standard design steps, was highlighted. Based on the optimum GPC mixture, future studies might evaluate the impact and abrasion resistance, structural performance, durability, and other mechanical properties of GPC.

Author Contributions: Conceptualization, S.K.; methodology, S.K.; software, S.K.; validation, S.K.; formal analysis, S.K.; investigation, S.K.; resources, S.K.; data curation, S.K.; writing-original draft preparation, S.K.; writing-review and editing, K.S.R.M.; visualization, K.S.R.M.; supervision, K.S.R.M.; project administration, S.K.; funding acquisition, S.K. All authors have read and agreed to the published version of the manuscript.

Funding: This research received no external funding.

Institutional Review Board Statement: Not applicable.

Informed Consent Statement: Not applicable.

Data Availability Statement: Not applicable.

Acknowledgments: The authors are grateful to the School of Civil Engineering, SASTRA Deemed University, for the support.

Conflicts of Interest: The authors declare no conflict of interest.

\section{References}

1. Esen, Y.; Yilmazer, B. Investigation of some physical and mechanical properties of concrete produced with barite aggregate. Sci. Res. Essays 2010, 5, 3826-3833.

2. Murali, G.; Gayathri, R.; Ramkumar, V.R.; Karthikeyan, K. Two statistical scrutinize of impact strength and strength reliability of steel Fibre-Reinforced Concrete. KSCE J. Civ. Eng. 2018, 22, 257-269. [CrossRef]

3. Strieder, E.; Hilber, R.; Stierschneider, E.; Bergmeister, K. FE-study on the effect of gradient concrete on early constraint and crack risk. Appl. Sci. 2018, 8, 246. [CrossRef]

4. Hu, H.T.; Lin, F.M.; Liu, H.T.; Huang, Y.F.; Pan, T.C. Constitutive modeling of reinforced concrete and prestressed concrete structures strengthened by fiber-reinforced plastics. Compos. Struct. 2010, 92, 1640-1650. [CrossRef]

5. Esen, Y.; Orhan, E. Investigation of the effect on the physical and mechanical properties of the dosage of additive in selfconsolidating concrete. KSCE J. Civ. Eng. 2016, 20, 2849-2858. [CrossRef] 
6. Zhang, P.; Zheng, Y.; Wang, K.; Zhang, J. A review on properties of fresh and hardened geopolymer mortar. Compos. Part B Eng. 2018, 152, 79-95. [CrossRef]

7. Davidovits, P.J. 30 Years of Successes and Failures in Geopolymer Applications. Market Trends and Potential Breakthroughs. In Proceedings of the Geopolymer 2002 Conference, Melbourne, VIC, Australia, 28-29 October 2002; pp. 1-16.

8. Habert, G.; D'Espinose De Lacaillerie, J.B.; Roussel, N. An environmental evaluation of geopolymer based concrete production: Reviewing current research trends. J. Clean. Prod. 2011, 19, 1229-1238. [CrossRef]

9. Sandanayake, M.; Gunasekara, C.; Law, D.; Zhang, G.; Setunge, S. Greenhouse gas emissions of different fly ash based geopolymer concretes in building construction. J. Clean. Prod. 2018, 204, 399-408. [CrossRef]

10. Bajpai, R.; Choudhary, K.; Srivastava, A.; Sangwan, K.S.; Singh, M. Environmental impact assessment of fly ash and silica fume based geopolymer concrete. J. Clean. Prod. 2020, 254, 120147. [CrossRef]

11. Puertas, F.; Palacios, M.; Manzano, H.; Dolado, J.S.; Rico, A.; Rodríguez, J. A model for the C-A-S-H gel formed in alkali-activated slag cements. J. Eur. Ceram. Soc. 2011, 31, 2043-2056. [CrossRef]

12. Yang, K.; Yang, C.; Magee, B.; Nanukuttan, S.; Ye, J. Establishment of a preconditioning regime for air permeability and sorptivity of alkali-activated slag concrete. Cem. Concr. Compos. 2016, 73, 19-28. [CrossRef]

13. Zhuang, X.Y.; Chen, L.; Komarneni, S.; Zhou, C.H.; Tong, D.S.; Yang, H.M.; Yu, W.H.; Wang, H. Fly ash-based geopolymer: Clean production, properties and applications. J. Clean. Prod. 2016, 125, 253-267. [CrossRef]

14. Hassan, A.; Arif, M.; Shariq, M. Use of geopolymer concrete for a cleaner and sustainable environment-A review of mechanical properties and microstructure. J. Clean. Prod. 2019, 223, 704-728. [CrossRef]

15. Zhang, P.; Gao, Z.; Wang, J.; Guo, J.; Hu, S.; Ling, Y. Properties of fresh and hardened fly ash/slag based geopolymer concrete: A review. J. Clean. Prod. 2020, 270, 122389. [CrossRef]

16. Junaid, M.T.; Khennane, A.; Kayali, O.; Sadaoui, A.; Picard, D.; Fafard, M. Aspects of the deformational behaviour of alkali activated fly ash concrete at elevated temperatures. Cem. Concr. Res. 2014, 60, 24-29. [CrossRef]

17. Somna, K.; Jaturapitakkul, C.; Kajitvichyanukul, P.; Chindaprasirt, P. NaOH-activated ground fly ash geopolymer cured at ambient temperature. Fuel 2011, 90, 2118-2124. [CrossRef]

18. Puligilla, S.; Mondal, P. Role of slag in microstructural development and hardening of fly ash-slag geopolymer. Cem. Concr. Res. 2013, 43, 70-80. [CrossRef]

19. Ariffin, M.A.M.; Bhutta, M.A.R.; Hussin, M.W.; Mohd Tahir, M.; Aziah, N. Sulfuric acid resistance of blended ash geopolymer concrete. Constr. Build. Mater. 2013, 43, 80-86. [CrossRef]

20. Khater, H.M. Studying the effect of thermal and acid exposure on alkali activated slag Geopolymer. MATEC Web Conf. 2014, 11, 01032. [CrossRef]

21. Ferdous, W.; Manalo, A.; Khennane, A.; Kayali, O. Geopolymer concrete-filled pultruded composite beams-Concrete mix design and application. Cem. Concr. Compos. 2015, 58, 1-13. [CrossRef]

22. Ding, Y.; Dai, J.G.; Shi, C.J. Mechanical properties of alkali-activated concrete: A state-of-the-art review. Constr. Build. Mater. 2016, 127, 68-79. [CrossRef]

23. Moon, J.; Bae, S.; Celik, K.; Yoon, S.; Kim, K.H.; Kim, K.S.; Monteiro, P.J.M. Characterization of natural pozzolan-based geopolymeric binders. Cem. Concr. Compos. 2014, 53, 97-104. [CrossRef]

24. Davidovits, J. Geopolymers and geopolymeric materials. J. Therm. Anal. 1989, 35, 429-441. [CrossRef]

25. Li, Z.; Zhang, S.; Zuo, Y.; Chen, W.; Ye, G. Chemical deformation of metakaolin based geopolymer. Cem. Concr. Res. 2019, 120, 108-118. [CrossRef]

26. Rees, C.A.; Provis, J.L.; Lukey, G.C.; van Deventer, J.S.J. The mechanism of geopolymer gel formation investigated through seeded nucleation. Colloids Surf. A Physicochem. Eng. Asp. 2008, 318, 97-105. [CrossRef]

27. Zhang, Y.J.; Li, H.H.; Wang, Y.C.; Xu, D.L. Geopolymer microstructure and hydration mechanism of alkali-activated fly ash-based geopolymer. Adv. Mater. Res. 2012, 374-377, 1481-1484. [CrossRef]

28. Davidovits, J. Geopolymers-Inorganic polymeric new materials. J. Therm. Anal. 1991, 37, 1633-1656. [CrossRef]

29. Palomo, A.; Shi, C.; Jiménez, A.F. New cements for the 21st century: The pursuit of an alternative to Portland cement. Cem. Concr. Res. 2011, 41, 750-763.

30. Hardjito, D.; Wallah, S.E.; Sumajouw, D.M.J.; Rangan, B.V. On the Development of Fly Ash-Based Geopolymer Concrete. ACI Mater. 2004, 101, 467-472.

31. Fernández-Jiménez, A.; Palomo, Á.; Vazquez, T.; Vallepu, R.; Terai, T.; Ikeda, K. Alkaline activation of blends of metakaolin and calcium aluminate. J. Am. Ceram. Soc. 2008, 91, 1231-1236. [CrossRef]

32. Duxson, P.; Lukey, G.C.; Separovic, F.; Van Deventer, J.S.J. Effect of alkali cations on aluminum incorporation in geopolymeric gels. Ind. Eng. Chem. Res. 2005, 44, 832-839. [CrossRef]

33. Ranjbar, N.; Talebian, S.; Mehrali, M.; Kuenzel, C.; Cornelis Metselaar, H.S.; Jumaat, M.Z. Mechanisms of interfacial bond in steel and polypropylene fiber reinforced geopolymer composites. Compos. Sci. Technol. 2016, 122, 73-81. [CrossRef]

34. Chindaprasirt, P.; Chareerat, T.; Sirivivatnanon, V. Workability and strength of coarse high calcium fly ash geopolymer. Cem. Concr. Compos. 2007, 29, 224-229. [CrossRef]

35. Kupaei, R.H.; Alengaram, U.J.; Jumaat, M.Z.B.; Nikraz, H. Mix design for fly ash based oil palm shell geopolymer lightweight concrete. Constr. Build. Mater. 2013, 43, 490-496. [CrossRef] 
36. Diaz-Loya, E.I.; Allouche, E.N.; Vaidya, S. Mechanical properties of fly-ash-based geopolymer concrete. ACI Mater. J. 2011, 108, 300-306. [CrossRef]

37. Akbarnezhad, A.; Huan, M.; Mesgari, S.; Castel, A. Recycling of geopolymer concrete. Constr. Build. Mater. 2015, 101, 152-158. [CrossRef]

38. Deb, P.S.; Nath, P.; Sarker, P.K. The effects of ground granulated blast-furnace slag blending with fly ash and activator content on the workability and strength properties of geopolymer concrete cured at ambient temperature. Mater. Des. 2014, 62, 32-39. [CrossRef]

39. Karthik, A.; Sudalaimani, K.; Vijayakumar, C.T. Durability study on coal fly ash-blast furnace slag geopolymer concretes with bio-additives. Ceram. Int. 2017, 43, 11935-11943. [CrossRef]

40. Patel, Y.J.; Shah, N. Enhancement of the properties of Ground Granulated Blast Furnace Slag based Self Compacting Geopolymer Concrete by incorporating Rice Husk Ash. Constr. Build. Mater. 2018, 171, 654-662. [CrossRef]

41. Sun, Z.; Lin, X.; Vollpracht, A. Pervious concrete made of alkali activated slag and geopolymers. Constr. Build. Mater. 2018, 189, 797-803. [CrossRef]

42. Li, X.; Rao, F.; Song, S.; Corona-Arroyo, M.A.; Ortiz-Lara, N.; Aguilar-Reyes, E.A. Effects of aggregates on the mechanical properties and microstructure of geothermal metakaolin-based geopolymers. Results Phys. 2018, 11, 267-273. [CrossRef]

43. Billong, N.; Kinuthia, J.; Oti, J.; Melo, U.C. Performance of sodium silicate free geopolymers from metakaolin (MK) and Rice Husk Ash (RHA): Effect on tensile strength and microstructure. Constr. Build. Mater. 2018, 189, 307-313. [CrossRef]

44. Nuaklong, P.; Sata, V.; Chindaprasirt, P. Influence of recycled aggregate on fly ash geopolymer concrete properties. J. Clean. Prod. 2016, 112, 2300-2307. [CrossRef]

45. Zhang, Y.; Sun, W.; Lin, W.; Zheng, K.; Sha, J.; Liu, S. Quantitative in situ study on the hydration process of K-PS geopolymer with ESEM. J. Southeast Univ. Nat. Sci. Ed. 2003, 33, 351-354.

46. Huang, G.; Ji, Y.; Li, J.; Hou, Z.; Jin, C. Use of slaked lime and Portland cement to improve the resistance of MSWI bottom ash-GBFS geopolymer concrete against carbonation. Constr. Build. Mater. 2018, 166, 290-300. [CrossRef]

47. Xie, T.; Ozbakkaloglu, T. Behavior of low-calcium fly and bottom ash-based geopolymer concrete cured at ambient temperature. Ceram. Int. 2015, 41, 5945-5958. [CrossRef]

48. Haddad, R.H.; Alshbuol, O. Production of geopolymer concrete using natural pozzolan: A parametric study. Constr. Build. Mater. 2016, 114, 699-707. [CrossRef]

49. Kupwade-Patil, K.; Allouche, E.N. Impact of Alkali Silica Reaction on Fly Ash-Based Geopolymer Concrete. J. Mater. Civ. Eng. 2013, 25, 131-139. [CrossRef]

50. Okoye, F.N.; Prakash, S.; Singh, N.B. Durability of fly ash based geopolymer concrete in the presence of silica fume. J. Clean. Prod. 2017, 149, 1062-1067. [CrossRef]

51. Rattanasak, U.; Chindaprasirt, P. Influence of $\mathrm{NaOH}$ solution on the synthesis of fly ash geopolymer. Miner. Eng. 2009, 22, 1073-1078. [CrossRef]

52. Stenie, W.; Dwantoro, H.; Sumajouw, D.J.M.; Vijaya, R.B. Performance of Fly Ash-Based Geopolymer Concrete Under Sulfate and Acid Exposure; Ed Nawy Symposium, American Concrete Institute: Indianapolis, IN, USA, 2005; pp. 153-156.

53. Al-Azzawi, M.; Yu, T.; Hadi, M.N.S. Factors Affecting the Bond Strength Between the Fly Ash-based Geopolymer Concrete and Steel Reinforcement. Structures 2018, 14, 262-272. [CrossRef]

54. Gunneswara Rao, T.D.; Alfrite, P.; Mallikarjuna Rao, G.; Andal, M. Fracture Parameters of Fly Ash and GGBS Based Geopolymer Concrete. Appl. Mech. Mater. 2015, 764-765, 1090-1094. [CrossRef]

55. Nasir, M.; Johari, M.A.M.; Yusuf, M.O.; Maslehuddin, M.; Al-Harthi, M.A. Synthesis of alkali-activated binary blended silicomanganese fume and ground blast furnace slag mortar. J. Adv. Concr. Technol. 2019, 17, 728-735. [CrossRef]

56. Saeli, M.; Novais, R.M.; Seabra, M.P.; Labrincha, J.A. Green geopolymeric concrete using grits for applications in construction. Mater. Lett. 2018, 233, 94-97. [CrossRef]

57. Saeli, M.; Tobaldi, D.M.; Seabra, M.P.; Labrincha, J.A. Mix design and mechanical performance of geopolymeric binders and mortars using biomass fly ash and alkaline effluent from paper-pulp industry. J. Clean. Prod. 2019, 208, 1188-1197. [CrossRef]

58. Dahou, Z.; Castel, A.; Noushini, A. Prediction of the steel-concrete bond strength from the compressive strength of Portland cement and geopolymer concretes. Constr. Build. Mater. 2016, 119, 329-342. [CrossRef]

59. Khan, M.S.H.; Castel, A.; Akbarnezhad, A.; Foster, S.J.; Smith, M. Utilisation of steel furnace slag coarse aggregate in a low calcium fly ash geopolymer concrete. Cem. Concr. Res. 2016, 89, 220-229. [CrossRef]

60. Karakoç, M.B.; Türkmen, I.; Maraş, M.M.; Kantarci, F.; Demirboğa, R. Sulfate resistance of ferrochrome slag based geopolymer concrete. Ceram. Int. 2016, 42, 1254-1260. [CrossRef]

61. Nuaklong, P.; Jongvivatsakul, P.; Pothisiri, T.; Sata, V.; Chindaprasirt, P. Influence of rice husk ash on mechanical properties and fire resistance of recycled aggregate high-calcium fly ash geopolymer concrete. J. Clean. Prod. 2020, 252, 119797. [CrossRef]

62. Kusbiantoro, A.; Nuruddin, M.F.; Shafiq, N.; Qazi, S.A. The effect of microwave incinerated rice husk ash on the compressive and bond strength of fly ash based geopolymer concrete. Constr. Build. Mater. 2012, 36, 695-703. [CrossRef]

63. Albitar, M.; Mohamed Ali, M.S.; Visintin, P. Experimental study on fly ash and lead smelter slag-based geopolymer concrete columns. Constr. Build. Mater. 2017, 141, 104-112. [CrossRef]

64. Albitar, M.; Mohamed Ali, M.S.; Visintin, P.; Drechsler, M. Effect of granulated lead smelter slag on strength of fly ash-based geopolymer concrete. Constr. Build. Mater. 2015, 83, 128-135. [CrossRef] 
65. Mo, K.H.; Yeoh, K.H.; Bashar, I.I.; Alengaram, U.J.; Jumaat, M.Z. Shear behaviour and mechanical properties of steel fibrereinforced cement-based and geopolymer oil palm shell lightweight aggregate concrete. Constr. Build. Mater. 2017, 148, 369-375. [CrossRef]

66. Islam, A.; Alengaram, U.J.; Jumaat, M.Z.; Bashar, I.I.; Kabir, S.M.A. Engineering properties and carbon footprint of ground granulated blast-furnace slag-palm oil fuel ash-based structural geopolymer concrete. Constr. Build. Mater. 2015, 101, 503-521. [CrossRef]

67. Kabir, S.M.A.; Alengaram, U.J.; Jumaat, M.Z.; Yusoff, S.; Sharmin, A.; Bashar, I.I. Performance evaluation and some durability characteristics of environmental friendly palm oil clinker based geopolymer concrete. J. Clean. Prod. 2017, 161, 477-492. [CrossRef]

68. Okoye, F.N.; Durgaprasad, J.; Singh, N.B. Fly ash/Kaolin based geopolymer green concretes and their mechanical properties. Data Brief 2015, 5, 739-744. [CrossRef]

69. Okoye, F.N.; Durgaprasad, J.; Singh, N.B. Mechanical properties of alkali activated flyash/Kaolin based geopolymer concrete. Constr. Build. Mater. 2015, 98, 685-691. [CrossRef]

70. Assi, L.N.; Deaver, E.; Elbatanouny, M.K.; Ziehl, P. Investigation of early compressive strength of fly ash-based geopolymer concrete. Constr. Build. Mater. 2016, 112, 807-815. [CrossRef]

71. Aliabdo, A.A.; Abd Elmoaty, A.E.M.; Salem, H.A. Effect of cement addition, solution resting time and curing characteristics on fly ash based geopolymer concrete performance. Constr. Build. Mater. 2016, 123, 581-593. [CrossRef]

72. Altwair, N.M.; Megat Johari, M.A.; Saiyid Hashim, S.F. Flexural performance of green engineered cementitious composites containing high volume of palm oil fuel ash. Constr. Build. Mater. 2012, 37, 518-525. [CrossRef]

73. Nuaklong, P.; Sata, V.; Chindaprasirt, P. Properties of metakaolin-high calcium fly ash geopolymer concrete containing recycled aggregate from crushed concrete specimens. Constr. Build. Mater. 2018, 161, 365-373. [CrossRef]

74. Çevik, A.; Alzeebaree, R.; Humur, G.; Niş, A.; Gülşan, M.E. Effect of nano-silica on the chemical durability and mechanical performance of fly ash based geopolymer concrete. Ceram. Int. 2018, 44, 12253-12264. [CrossRef]

75. Cao, Y.F.; Tao, Z.; Pan, Z.; Wuhrer, R. Effect of calcium aluminate cement on geopolymer concrete cured at ambient temperature. Constr. Build. Mater. 2018, 191, 242-252. [CrossRef]

76. Hadi, M.N.S.S.; Farhan, N.A.; Sheikh, M.N. Design of geopolymer concrete with GGBFS at ambient curing condition using Taguchi method. Constr. Build. Mater. 2017, 140, 424-431. [CrossRef]

77. Özen, S.; Alam, B. Compressive strength and microstructural characteristics of natural zeolite-based geopolymer. Period. Polytech. Civ. Eng. 2018, 62, 64-71. [CrossRef]

78. Xu, Z.; Wu, D.; Zheng, L.; Li, D.; Peng, X. Experimental study on geopolymer synthesis from activated zeolite. Disaster Adv. 2013, 6, 159-163.

79. Assi, L.N.; Eddie Deaver, E.; Ziehl, P. Effect of source and particle size distribution on the mechanical and microstructural properties of fly Ash-Based geopolymer concrete. Constr. Build. Mater. 2018, 167, 372-380. [CrossRef]

80. Standard Specification for Coal Fly Ash and Raw or Calcined Natural Pozzolan for Use in Concrete; ASTM C618-17a; ASTM International: West Conshohocken, PA, USA, 2017.

81. Coarse and Fine Aggregate for Concrete—Specification (Third Revision); IS 383: 2016; Bureau of Indian Standards: New Delhi, India, 2016; Volume 19.

82. Method of Tests for Strength of Concrete (Eighteenth Reprint 2006); IS 516; 1959; Bureau of Indian Standards: New Delhi, India, 2006.

83. Jithendra, C.; Elavenil, S. Role of superplasticizer on GGBS based Geopolymer concrete under ambient curing. Mater. Today Proc. 2019, 18, 148-154. [CrossRef]

84. Morsy, M.S.; Alsayed, S.H.; Al-Salloum, Y.; Almusallam, T. Effect of Sodium Silicate to Sodium Hydroxide Ratios on Strength and Microstructure of Fly Ash Geopolymer Binder. Arab. J. Sci. Eng. 2014, 39, 4333-4339. [CrossRef]

85. Škvára, F.; Kopecký, L.; Němeček, J.; Bittnar, Z. Microstructure of geopolymer materials based on fly ash. Ceram. Silik. 2006, 50, 208-215. 